\title{
Chemical Pollution Risks for Many Drinking Water Sources in Baghdad City, Iraq
}

\author{
Mohammed A. B. Abdul Jabar ${ }^{1 *}$, Jinan Azeez Thabit ${ }^{2}$ \\ ${ }^{1}$ College of Science, Al-Karkh University of Science, Hayfa Street, Baghdad 10001, Iraq \\ ${ }^{2}$ Industrial Property Department, Central Organization for Standardization and Control Quality, Ministry of Planning, \\ Al Jadryia St., Baghdad 10070, Iraq
}

Received: 19 March 2020

Accepted: 18 April 2020

\begin{abstract}
To determine contamination levels of pollutants in all of Baghdad's drinking water sources, all samples were taken from different water sources which are used in research areas and examined by AAS, $\mathrm{pH}$, turbidity and TDS meters. The results indicate the mean concentrations of heavy elements $(\mathrm{Cd}, \mathrm{Co}$, $\mathrm{Pb}$, and $\mathrm{Cr}$ (except for the concentration of chromium in one site)) were within WHO permissible limit> in the samples of drinking water were higher than the international limits. Mean concentrations of other heavy elements $(\mathrm{Cu}, \mathrm{Fe}$, and $\mathrm{Ni})$ in water samples were below WHO recommendations permitted limits. The findings of the sample $\mathrm{pH}$ values were within the international acceptable limits. Turbidity values for all samples were within the Iraqi and global limits except 4 sites that exceeded acceptable WHO and Iraqi guideline limits. The levels of TDS in all samples were also lower than WHO except the samples in two sites which show levels of TDS higher than the Iraqi and WHO limits. According to the results above, all the drinking water projects in the Tigris River and water wells in Baghdad city must be monitored, Adequate and new drinking water treatment methods shall also be used. The Heavy Pollution Index (HPI) findings indicate that the drinking water sources in the city of Baghdad have been substantially polluted with $\mathrm{Cd}$, $\mathrm{Co}$ and $\mathrm{Pb}$.
\end{abstract}

Keywords: heavy metals, drinking water, Tigris River, Baghdad

\section{Introduction}

Following decades of corruption during the wars and trade restrictions of the $1980 \mathrm{~s}$ and $1990 \mathrm{~s}$, and the serious environmental damage caused by the US occupation of Iraq after 2003, Iraq's pollution levels reached a peak. Where the water quality in Iraq's main

*e-mail: mohammed.a.baset1980@gmail.com rivers: Tigris and Euphrates has greatly degraded and is considered the country's life-blood. Tigris water contamination is the worst, and is one of Iraqis' major sources of cancer [1]. High levels of pollution in recent years are due to various factors including directly from wars, factories, and the discharge of water from houses and hospitals directly into the Tigris River which contains many polluted materials (chemicals, pesticides, and agricultural fertilizers). Certain factors that aren't explicitly due to government negligence and the lack 
of a systematic management strategy to tackle these pollution causes. Since 2003, all governments in Iraq have not assumed responsibility for this environmental disaster and did not recognize the issues or even try to find solutions to the rate of massive pollution and raise it [2].

Researches that shed light on the levels of chemical contamination for drinking water sources in Iraq in general and Baghdad, in particular, are few compared to the effect of the serious water pollution that Iraq is suffering at present in addition to the absence of accurate governmental statistics for the levels of water pollution of drinking water sources in actual. Thus, we decided to start an actual study to measure and evaluate concentration for some heavy elements, $\mathrm{pH}$, Turbidity and Total Dissolved Solids (TDS) for several drinking water sources in the city of Baghdad. Drinking water includes various dangerous heavy metals, including lead, cadmium, chromium, copper, cobalt, iron, nickel and others; which are considered to be at high levels that threaten the lives of humans and causing many chronic diseases and cancer [3].

Many recent studies have demonstrated major environmental and public health effects of the heavy elements. The entry of these elements into the human body leads to toxic effects on the human body or organisms [4]. The lead element $(\mathrm{Pb})$ is one of the most dangerous elements that affect the body system and cause serious damage, especially to children. Lead is also a contributing factor for cancer [5]. The accumulation of cadmium element $(\mathrm{Cd})$ within the human body when its concentration exceeds safe critical limits, causes serious health damage and is classified as a group I carcinogen; it is harmful to the kidney, liver, reproductive system and nervous system [6]. The chromium $(\mathrm{Cr})$ element has several oxidants; hexagon chromium (VI) is quite toxic. Risks of this type of the human body include lung cancer, skin rash, gastric disorders and ulcers, breathing disorders, weakness in the efficiency of the immune system and other [7]. Increasing the concentration of the copper $(\mathrm{Cu})$ element in the body leads for poisoning, heart problems, and jaundice and ultimately can lead to death [8]. Although cobalt $(\mathrm{Co})$ is considered a heavy element, its effect as an element is quite different from other heavy elements. Cobalt is a part of vitamin B-12 synthesis and is important for bone and muscle growth, but increasing the concentration of cobalt in the human body leads to atrophy of the heart muscle, and hypothyroidism [9]. Although the iron (Fe) level is not harmful in itself, iron is classified in drinking water as a secondary pollutant. If iron levels are too high, serious health effects will be created with the liver, heart, and pancreas in addition to the risk of diabetes and anemia [10]. As it is known, the nickel element is not deposited in the human body but is excreted through urine, feces, and sweat. However, while accumulating, nickel compounds in the body can lead to many dangerous diseases, such as contact dermatitis, pulmonary fibrosis, renal cardiovascular disease and lung cancer [10]. For $\mathrm{pH}$, it does not effectively affect human life or the environment, but it is recommended that the $\mathrm{pH}$ is less than 10 to reduce corrosion in the water pipes as well as to maintain the taste, smell and appearance of water [12]. Several studies have shown an important relationship between drinking water and cancer concentration rates of TDS, coronary heart disease. Mortality rates from cancer and heart disease increase when the TDS concentrations increase in drinking water $[13,17]$.

Despite the unprecedented serious environmental pollution in the Baghdad city (the capital of Iraq), there is little attention by the researchers, the government, and international organizations paid to this site due to the lack of funds allocated for research in addition to the ongoing, financial crisis in Iraq, and the absence of law to protect rivers and lakes from dumping hazardous waste into freshwater [18-21].

Baghdad is actually one of Iraq's most populated cities located in the Middle East, having the most polluted population, especially pollution of the Tigris River and other sources of drinking water in Baghdad. This pollution in some places is serious in dozens of times than global standards. If environmental pollution, especially the pollution of the Tigris River will be continuously neglected, this will eventually lead to the spread of to tens of thousands of cases of cancerous diseases and other fatal diseases; the effects of this pollution are now being noticed [22].

This work primarily seeks to quantify and calculate the percentage of cadmium, chromium, copper, cobalt, iron, zinc, and nickel pollution, as well as $\mathrm{pH}$, turbidity, and TDS in Baghdad's major drinking water sources, including the Tigris River, water wells, bottled drinking water, and Tap Water. This study is considered as the first actual attempt to measure various basic drinking sources in Baghdad. The result of the research can be used to reduce pollution, and improve drinking water quality, especially in Baghdad and Iraq in general.

\section{Material and Methods}

\section{Geographical Study Sites}

The research sites (tap water, water wells, and the Tigris River (Fig. 1)) are situated in separate areas of Al-Rusafa and Al-Karkh (City of Baghdad is split into two parts: provinces Al-Rusafa and Al-Karkh) (Fig. 2), while bottled drinking water (Pearl, Al-saad and Aquafina) were purchased from different shops (used by about $70 \%$ of the population) in Baghdad city, and we chose the time to study samples in the rainy season in Iraq (Table 1).

\section{Sample Collection}

Water samples were randomly obtained from several locations inside Baghdad (Figs 3 and 4). All 


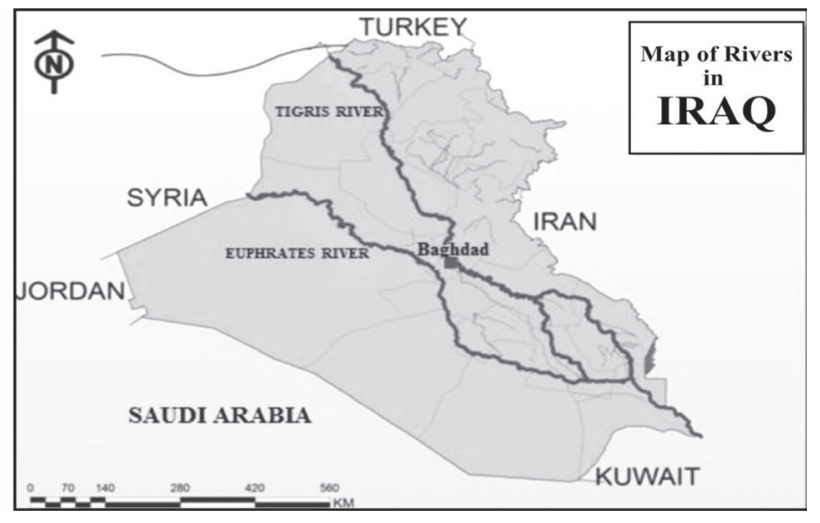

Fig. 1. The map of Iraq shows the Tigris and Euphrates rivers, modified by the authors.

the samples were collected in plastic sealed tubes. The collection process took about 5 months (from November 2018 to March 2019). Drinking water samples collected from the following sites: S1Al-A'amel Neighborhood (4 samples), S2- Kasraa Wa Ataash Neighborhood (5 samples), S3- Hayfaa Street
(4 samples), S4- Al Fadhilia Neighborhood (3 samples), S5- Bab Al-Moatham Neighborhood (5 samples), S6- Al-Sarafiya Bridge, S7- Pearl company (bottled drinking water- 7 samples), S8- Al-saad company (bottled drinking water- 6 samples) and S9- Aquafina company (bottled drinking water- 4 samples).

\section{Instrumentation}

All samples were analyzed by Atomic Absorption Spectrometer (AAS, model: novAA 400 - Analytik Jena, 2005, Germany). The drinking water tests were conducted using the Traditional Water and Wastewater Examining Process [23]. All instrumental parameters were established according to the recommendations of the manufacturer and the chemicals used were of analytical grade type $[24,25]$. The $\mathrm{pH}$ and turbidity for all drinking water samples were examined by $\mathrm{pH}$ meter (model: WTW, Germany) and turbidity meter (model: HACH, USA), while the total dissolved solids were examined by a handy TDS meter (Millipore filter device, model: LABSCO, Germany). The drinking water samples were measured in the laboratories of the Iraqi Ministry of Science and Technology.

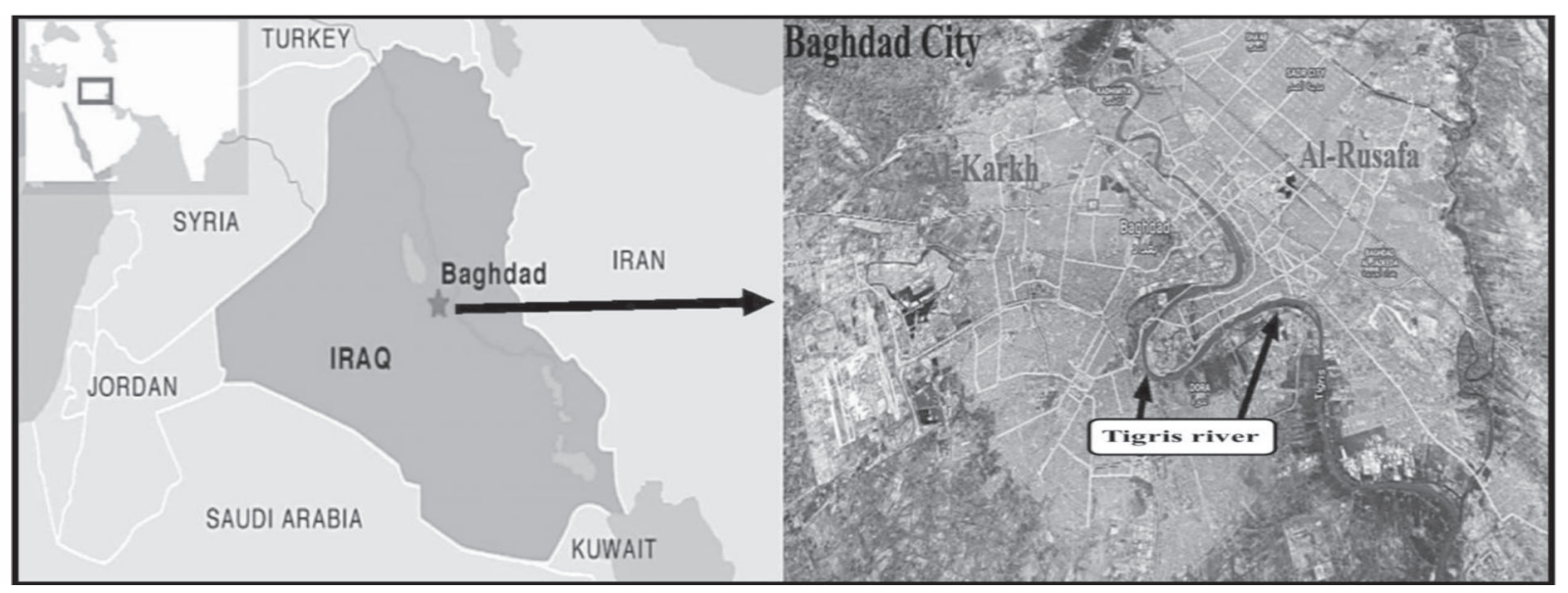

Fig. 2. Location of Tigris River in Baghdad City (showing how the Tigris River splits Baghdad city into Al-Rusafa and Al-Karkh regions).

Table 1. Geographical Study Sites, Samples Locations and Date of Collection in Baghdad city.

\begin{tabular}{|c|c|c|c|}
\hline Sample № & Sample Location & Geographical Study Sites & Date of collection \\
\hline S1 & Tap Water & Al-A'amel Neighborhood & $12-11-2018$ \\
\hline S2 & Tap Water & Kasraa Wa Ataash Neighborhood & $15-11-2018$ \\
\hline S3 & Water Well & Hayfaa Street & $13-11-2018$ \\
\hline S4 & Water Well & Al Fadhilia Neighborhood & $22-11-2018$ \\
\hline S5 & Tigris River & Al-Sab Al-Moatham Neighborhood & $05-12-2018$ \\
\hline S6 & Tigris River & Pearl Company & $05-12-2018$ \\
\hline S7 & Bottled Drinking Water & Al-saad Company & $12-11-2018$ \\
\hline S8 & Bottled Drinking Water & Aquafina Company & $04-03-2019$ \\
\hline S9 & Bottled Drinking Water & & $04-03-2019$ \\
\hline
\end{tabular}




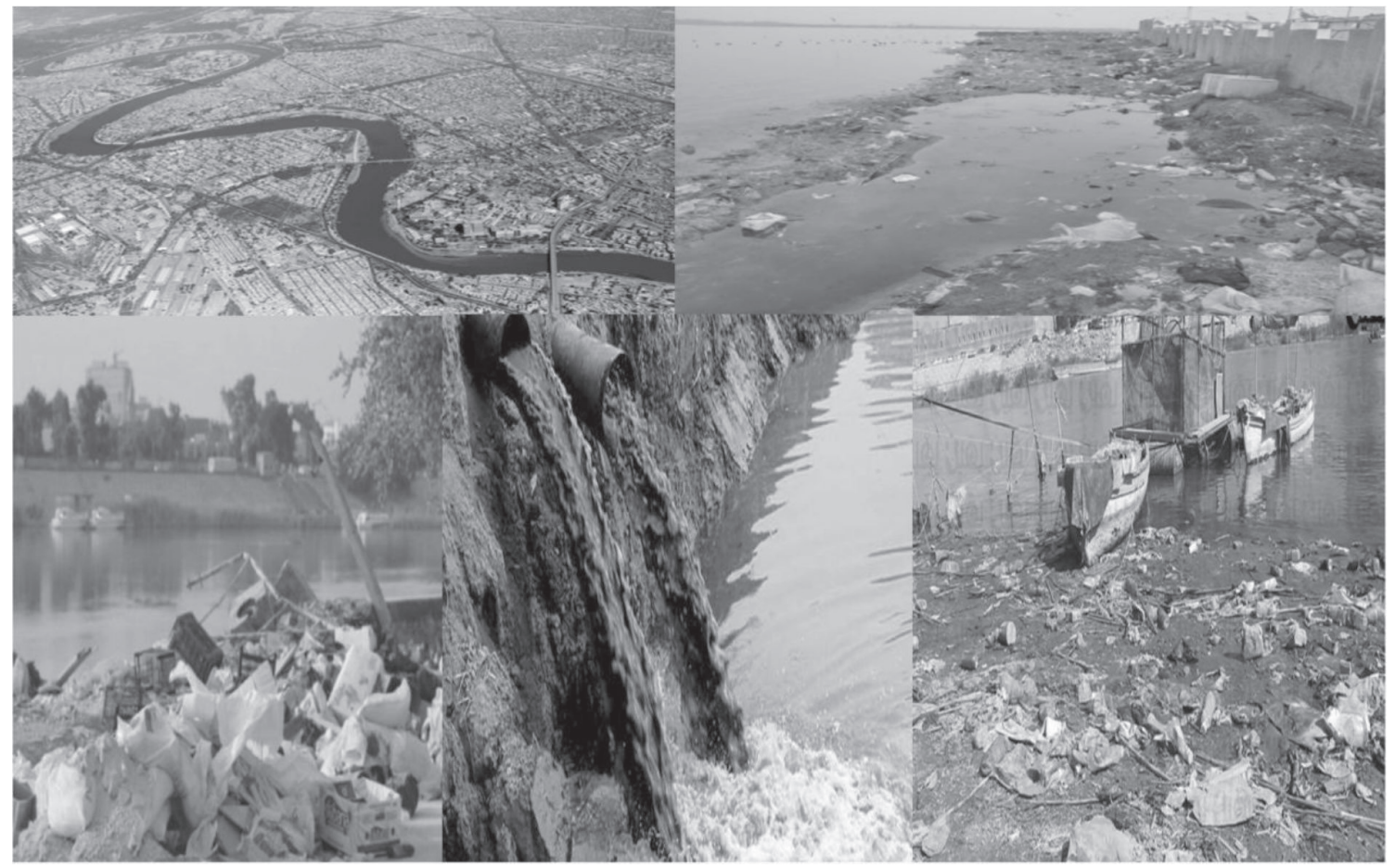

Fig. 3. Some pictures of the Tigris River and its pollution (the pictures were taken in 2018 and 2019).

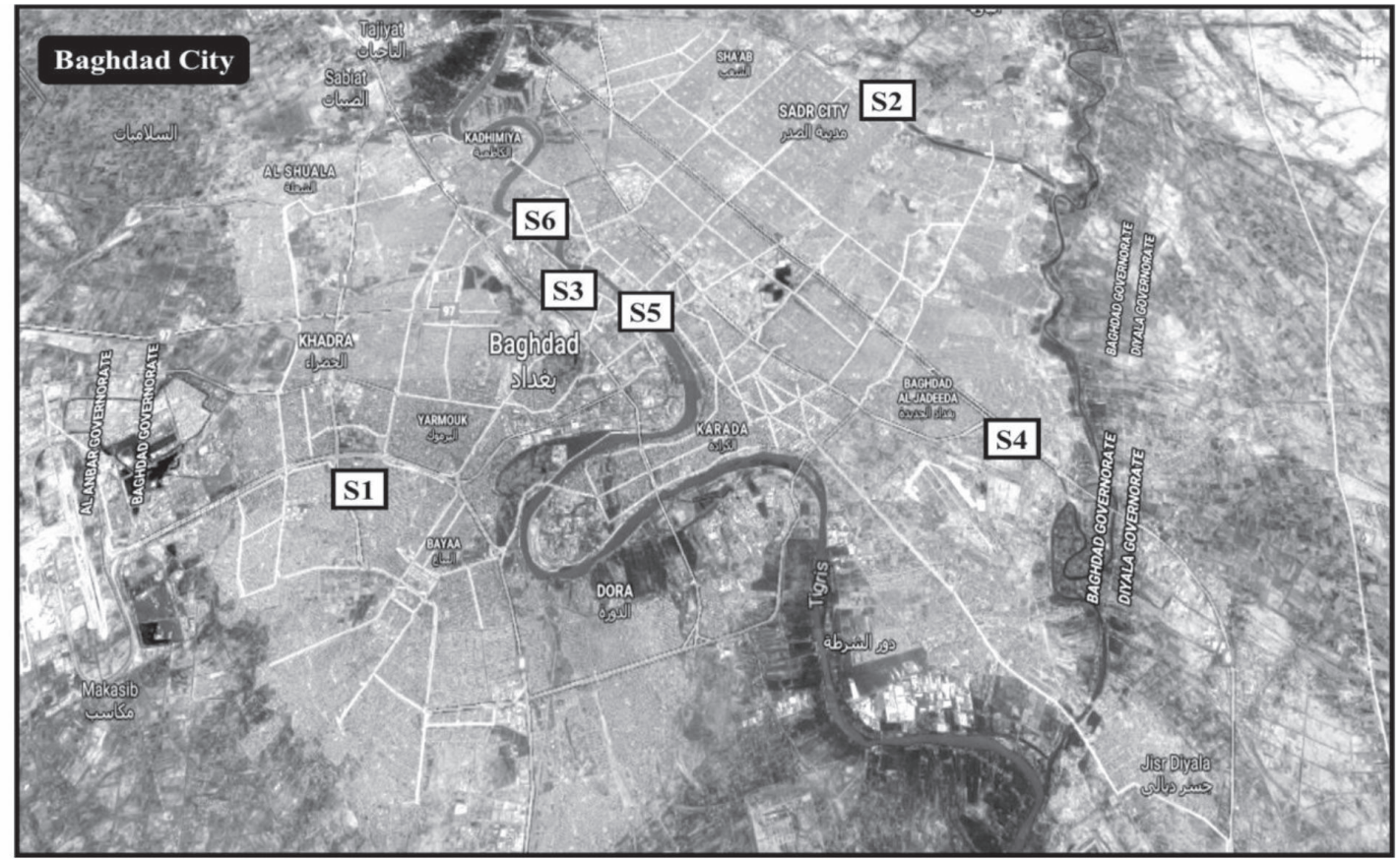

Fig. 4. Various sites for collecting drinking water samples in the Baghdad city.

Heavy Metal Quality Index (HPI)

We used the Heavy Metal Pollution Index (HPI) to assess the consistency of the heavy metals water for drinking water supplies in Baghdad City. HPI is calculated using the equation given below:

$$
\mathrm{HPI}=\sqrt{ }\left[\left(\mathrm{C}_{\mathrm{e}} / \mathrm{S}_{\mathrm{e}}\right)^{2}{ }_{\text {max }}+\left(\mathrm{C}_{\mathrm{e}} / \mathrm{S}_{\mathrm{e}}\right)^{2}{ }_{\text {min }}\right] / 2
$$

...where $\mathrm{C}_{\mathrm{e}}$ is each element's recorded concentration, and where $\mathrm{S}_{\mathrm{e}}$ is the normal permissible value for the element. HPI is categorized as follows into five groups: $<1$ (no effect), 1-2 (slightly affected), 2-3 (medium affected), 3-5 (strongly affected) and $>5$ (extremely affected); [26]. 
Table 2. Guideline levels for certain drinking water heavy elements (mg/l).

\begin{tabular}{|c|c|c|c|c|c|}
\hline Heavy Element & WHO & Iraqi Standard & European Union & Canada & United States \\
\hline Cadmium, $\mathrm{Cd}$ & 0.003 & 0.003 & 0.005 & 0.005 & 0.005 \\
\hline Chrome, $\mathrm{Cr}$ & 0.050 & 0.050 & 0.050 & 0.050 & 0.100 \\
\hline Copper, $\mathrm{Cu}$ & 2.000 & 1.000 & 2.000 & 1.000 & 1.300 \\
\hline Cobalt, $\mathrm{Co}$ & $0.001-0.002$ & - & 0.00033 & - & - \\
\hline Iron, $\mathrm{Fe}$ & 0.300 & 0.300 & 0.200 & 0.300 & 0.300 \\
\hline Lead, $\mathrm{Pb}$ & 0.010 & 0.010 & 0.010 & 0.010 & 0.015 \\
\hline Nickel, $\mathrm{Ni}$ & 0.070 & 0.020 & 0.020 & 0.010 & 0.100 \\
\hline
\end{tabular}

Table 3. The standard values for drinking water for different physico-chemical parameters include $\mathrm{pH}$, turbidity and total dissolved solids (TDS).

\begin{tabular}{|c|c|c|c|c|c|}
\hline $\begin{array}{c}\text { Physicochemical } \\
\text { Parameters }\end{array}$ & WHO & Iraqi Standard & European Union & Canada & United States \\
\hline $\mathrm{pH}$ & $6.5-8.5$ & $6.5-8.5$ & $6.5-9.5$ & $6.5-8.5$ & $6.5-8.5$ \\
\hline TDS (mg/l) & 1000 & 1000 & 500 & 500 & 500 \\
\hline Turbidity (N.T.U) & 5 & 5 & 4 & $0.1-1.0$ & $0.5-1.0$ \\
\hline
\end{tabular}

\section{Results and Discussion}

Several global organizations have established appropriate levels of concentrations for heavy metals, such as the World Health Organization (WHO) and others, and other physicochemical parameters as seen in Tables 2 and 3 [27-31].

Results of the examined samples of drinking water are presented in Table 4 and Fig. 5. Fig. 5 show the results for the seven toxic chemicals concentration which are measured in this study: Cadmium, chrome, Copper, Cobalt, Iron, Lead, and Nickel. Physiochemical parameters ( $\mathrm{pH}, \mathrm{TDS}$, and Turbidity) values for drinking water samples which were selected from many sites in Baghdad City are given in Table 4.

Table 4. Some physicochemical parameter values for drinking water samples, which selected from different locations in Baghdad City.

\begin{tabular}{|c|c|c|c|}
\hline Sample № & $\mathrm{pH}$ & TDS (mg/L) & Turbidity (N.T.U) \\
\hline S1 & 7.64 & 296 & 2.49 \\
\hline S2 & 7.84 & 341 & 9.44 \\
\hline S3 & 7.67 & 2740 & 2.70 \\
\hline S4 & 7.32 & 1720 & 51.09 \\
\hline S5 & 7.87 & 386 & 62.23 \\
\hline S6 & 7.91 & 312 & 30.23 \\
\hline S7 & 6.62 & 5 & 0.08 \\
\hline S8 & 7.11 & 36 & 1.40 \\
\hline S9 & 6.80 & 22 & 0.15 \\
\hline
\end{tabular}

The high concentrations of cadmium (Cd) in drinking water are quite damaging to the environment, to life and to the human body, which leads to different diseases, especially kidney failure, and various cancers diseases. The mean concentrations of cadmium $(\mathrm{Cd})$ in samples of drinking water (Fig. 6) for various areas of the city of Baghdad is as follows: Site 1$(0.130 \pm 0.07)$, Site $2-(0.170 \pm 0.02)$, Site $3-(0.180 \pm 0.09)$, Site 4- $(0.170 \pm 0.06)$, Site 5- $(0.180 \pm 0.06)$, Site 6$(0.130 \pm 0.03)$, Site $7-(0.120 \pm 0.02)$, Site $8-(0.170 \pm 0.05)$ and Site 9- $(0.011 \pm 0.08)$. According to WHO, Iraqi standards and other standards (Table 2), the maximum allowed cadmium concentration in drinking water must be between $0.003-0.005 \mathrm{mg} / \mathrm{L}$. The results show that cadmium concentrations in measured drinking water samples are quite high and this is why we are concerned about a humanitarian disaster in Baghdad if the water is not treated as soon as possible. The cadmium pollution in Bab Al-Moatham Neighborhood (Tigris River) and Haifa Street (Water Well) is about 60 times more than the international limit, while cadmium concentration in Kasraa Wa Ataash Neighborhood (Tap Water), Al Fadhilia Neighborhood (Water Well) and Al-saad Company (Bottled Drinking Water) is 56 times more than the permitted concentration. In other sites, cadmium concentration is increased 43 times (Al-A'amel Neighborhood (Tap Water) and Al-Sarafiya Bridge (Tigris River), 40 times in Pearl company (Bottled Drinking Water) and 4 times in Aquafina company (Bottled Drinking Water) respectively more than the limits allowed concentrations according to Iraqi and international standards. In Baghdad the highest concentration of $\mathrm{Cd}$ pollution is in the Tigris River and water wells. This can be shown as follows: 


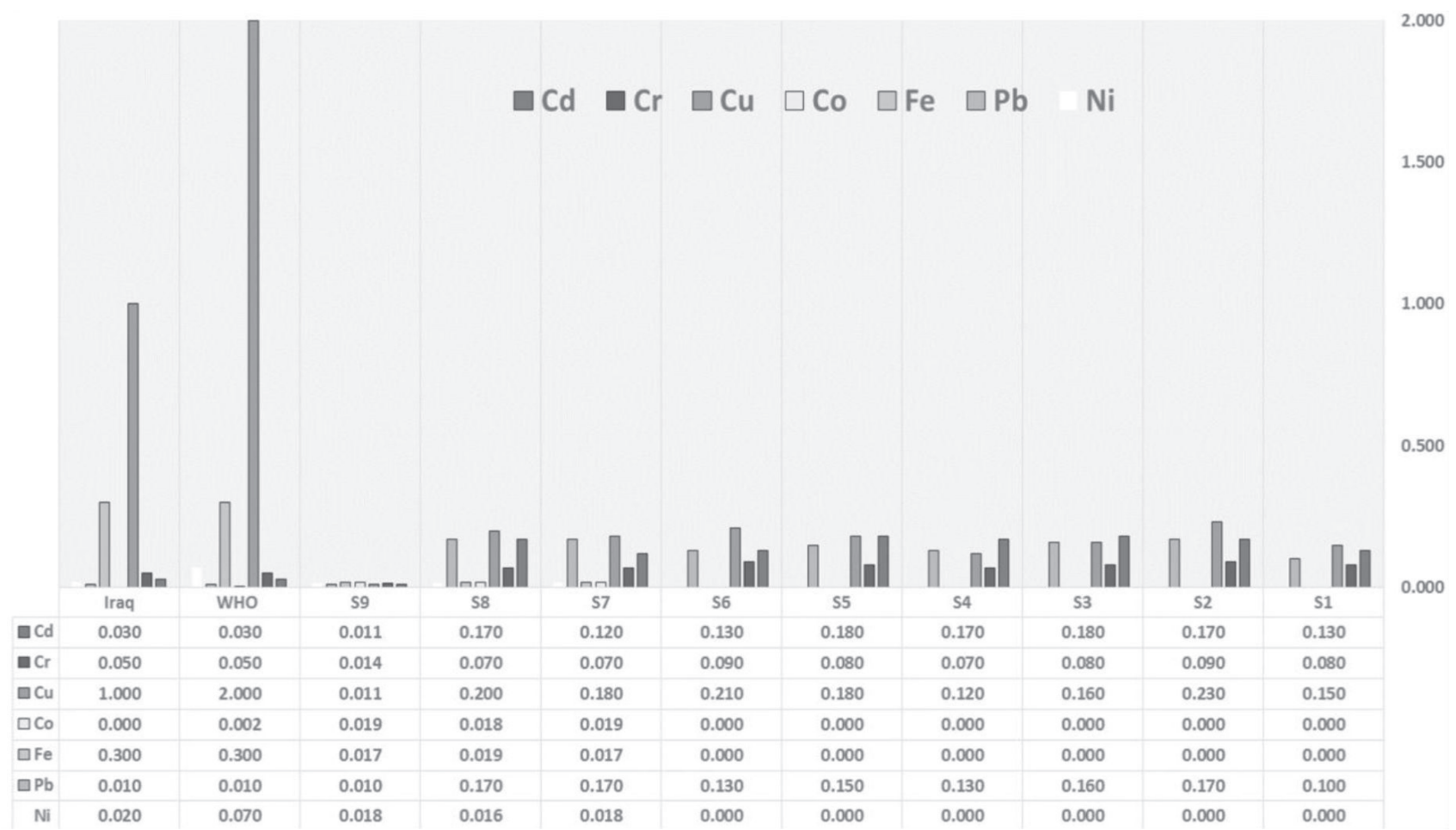

Fig. 5. Plot of mean concentration $(\mathrm{mg} / \mathrm{L})$ versus heavy elements $(\mathrm{Cd}, \mathrm{Cr}, \mathrm{Cu}, \mathrm{Co}, \mathrm{Fe}, \mathrm{Pb}$, and $\mathrm{Ni}$ ) samples selected from different sites in Baghdad City.

\section{Cd (mg/L)}

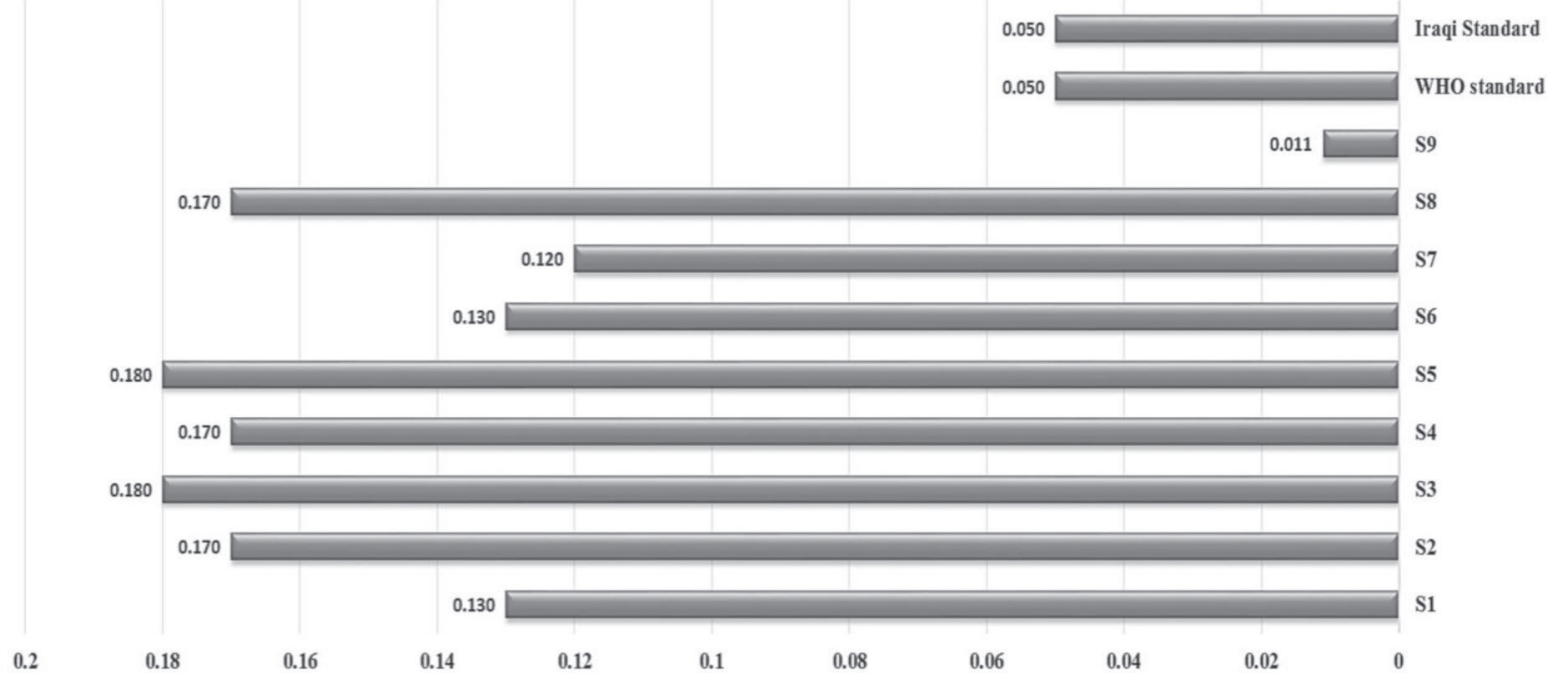

Fig. 6. Concentrations of $\mathrm{Cd}$ in different studied sites.

These results can be shown as follows: Tigris River and Water Well $>$ Tap Water and Bottled Drinking Water.

In drinking water samples chromium $(\mathrm{Cr})$ mean concentrations which were taken from Taps Water ranged between $0.080 \pm 0.02 \mathrm{mg} / \mathrm{L}$ (S1- Al-A'amel Neighborhood) to $0.090 \pm 0.04 \mathrm{mg} / \mathrm{L}$ (S2- Kasraa Wa Ataash Neighborhood); chromium concentrations in sample collected from Water Wells ranged between $0.080 \pm 0.05 \mathrm{mg} / \mathrm{L}$ (S3- Hayfaa Street) to
0.070 $\pm 0.01 \mathrm{mg} / \mathrm{L}$ (S4- Al Fadhilia Neighborhood), while they ranges from $0.080 \pm 0.07 \mathrm{mg} / \mathrm{L}$ (S5- Bab Al-Moatham Neighborhood) to $0.090 \pm 0.04 \mathrm{mg} / \mathrm{L}$ (S6- Al-Sarafiya Bridge) in the samples taken from the Tigris River. Chromium concentrations measurements in Bottled Drinking Water samples that were purchased from different regions of Baghdad city were $0.070 \pm 0.09 \mathrm{mg} / \mathrm{L}$ (S7- Aquafina Company), $0.070 \pm 0.05 \mathrm{mg} / \mathrm{L}$ (S8- Al-saad Company) and 


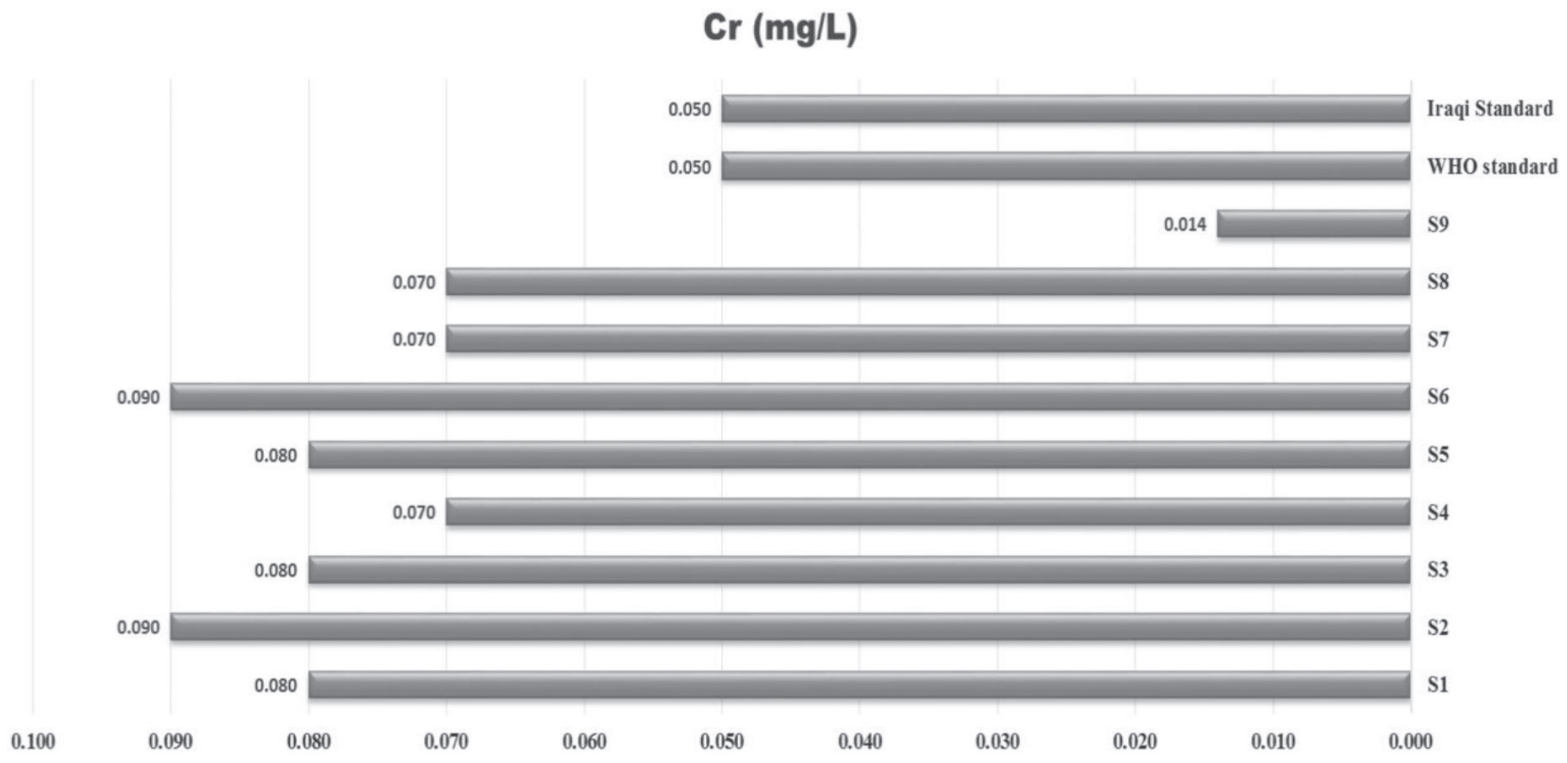

Fig. 7. Concentrations of $\mathrm{Cr}$ in different studied sites.

$0.014 \pm 0.03 \mathrm{mg} / \mathrm{L}$ (S9- Pearl Company). In the sites from $\mathrm{S} 1$ to $\mathrm{S} 8$, levels of chromium concentrations are between 1.5-2 times higher than global standards (Fig. 7) and can be attributable to many reasons such as remnants of war weapons, soil pollution, and others, whilst the chromium concentrations in bottled drinking water are below reasonable limits (Aquafina company). The Tigris River and Tap water are the highest concentration of drinking water pollution by $\mathrm{Cr}$ in Baghdad. This can be described as: Tigris River and Tap Water $>$ Water Well $>$ Bottled Drinking Water.

Copper is present in river water and other drinking water supplies due to industrial waste pollution as well as the spraying of agricultural pesticides. Copper is one of the basic elements of the human body, where the human body fulfills its needs of copper by eating, drinking and breathing. However, high concentrations of copper are harmful to human health. The concentrations of the copper $(\mathrm{Cu})$ in Baghdad city, the scale from 0.011 to $0.230 \mathrm{mg} / \mathrm{L}$ in our sample sites (Fig. 8). All drinking water samples show low copper mean concentrations (Site 1- 0.150 $\pm 0.09 \mathrm{mg} / \mathrm{L}$; Site 2- $0.230 \pm 0.02 \mathrm{mg} / \mathrm{L}$; Site 3- $0.160 \pm 0.09 \mathrm{mg} / \mathrm{L}$; Site 4- $0.120 \pm 0.08 \mathrm{mg} / \mathrm{L}$; Site 5- $0.180 \pm 0.05 \mathrm{mg} / \mathrm{L}$; Site 6- 0.210 $\pm 0.01 \mathrm{mg} / \mathrm{L}$; Site 7- $0.180 \pm 0.07 \mathrm{mg} / \mathrm{L}$; Site 8- $0.200 \pm 0.03 \mathrm{mg} / \mathrm{L}$; Site 9$0.011 \pm 0.06 \mathrm{mg} / \mathrm{L})$ compared with WHO, Iraqi and other organizations standard (Table 2).

There is an important relationship between cancer diseases, and the high concentrations of cobalt and its compounds in the human body; increasing the concentration of cobalt in drinking water in a particular area leads to an increase in the proportion of people with different cancers diseases [32]. Cobalt (Co) concentrations in bottled drinking water samples clarified that the Pearl Company's mean concentration of cobalt in water samples was $0.019 \pm 0.01$, while

\section{Cu (mg/L)}

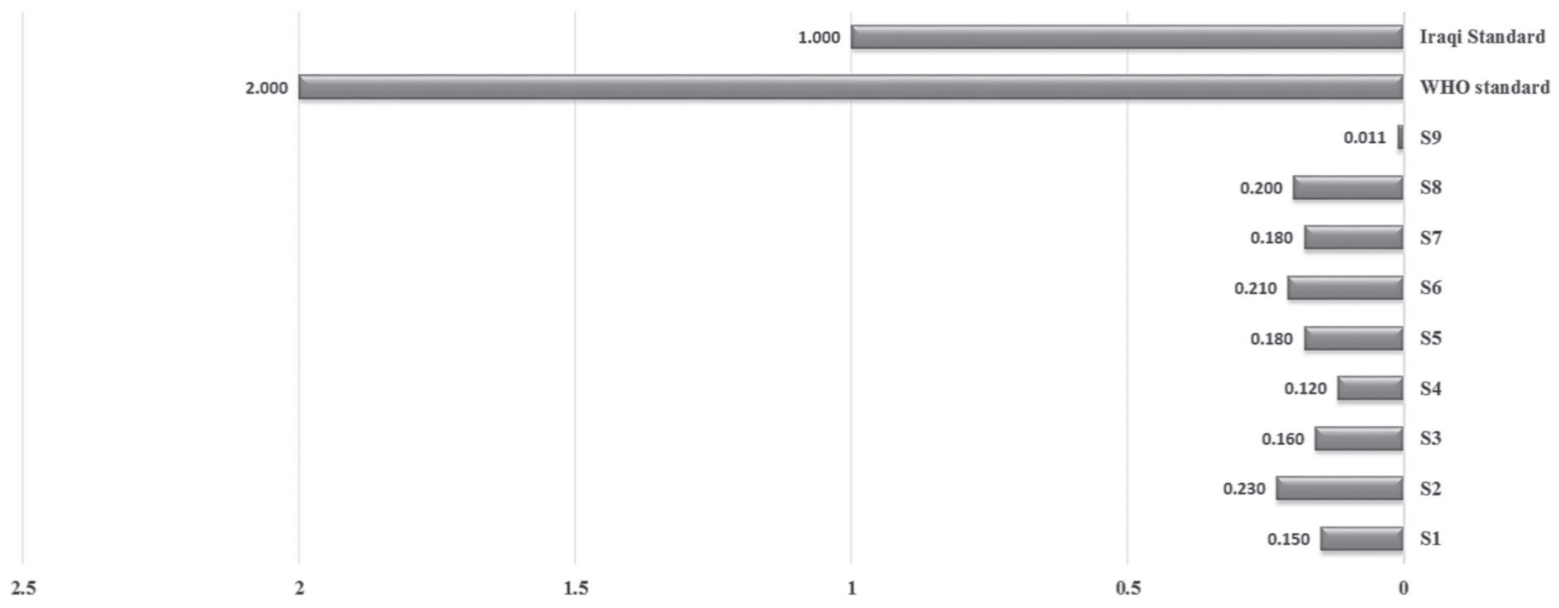

Fig. 8. Concentrations of $\mathrm{Cu}$ in different studied sites. 


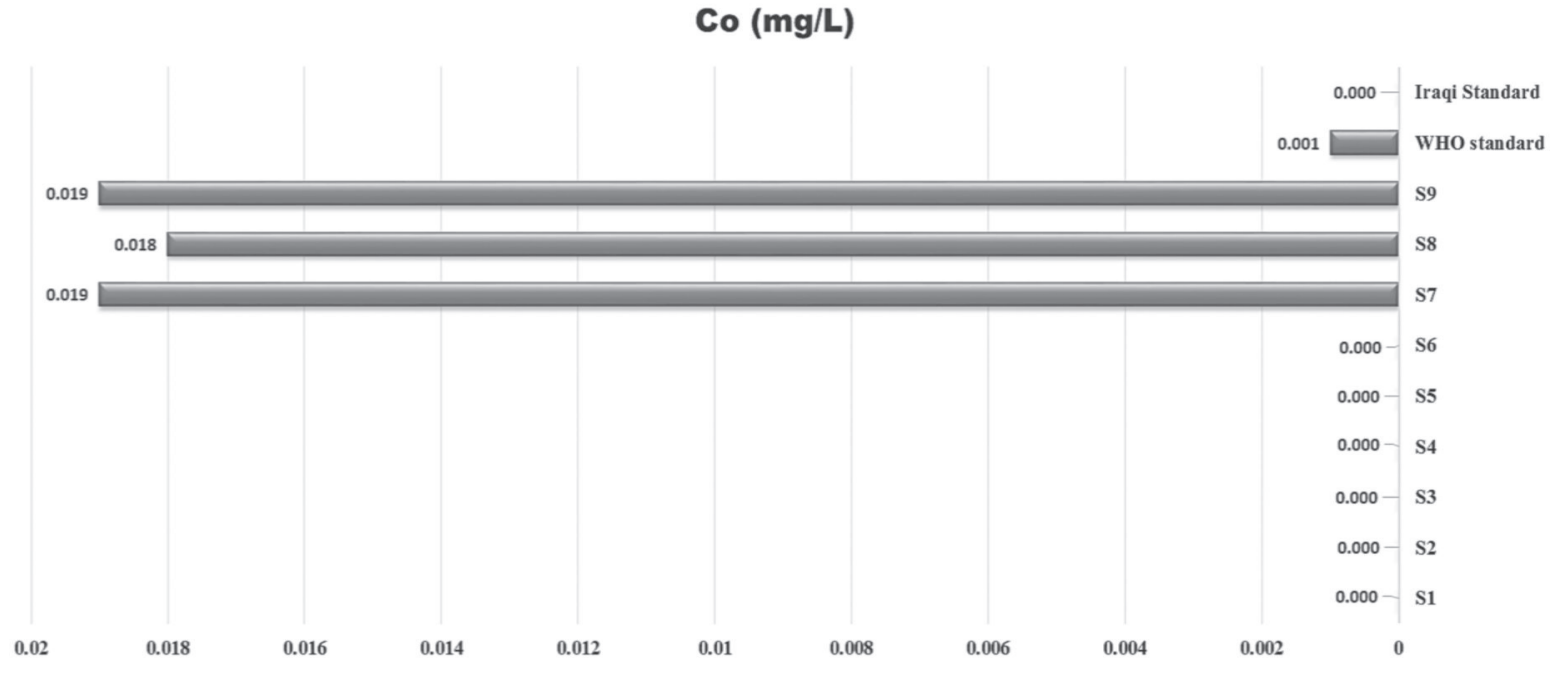

Fig. 9. Concentrations of Co in different studied sites.

the mean cobalt (Co) Concentration in the Al-saad Company water samples were $0.018 \pm 0.03$ and the mean concentration of cobalt element in Aquafina Company water samples was $0.019 \pm 0.03$. It can be noticed that cobalt pollution of bottled drinking water samples in two companies (Pearl and Aquafina) is about 19 times higher than WHO standard and in Al-saad Company bottled drinking water samples it increases 18 times compared with the international limit $(0.001 \mathrm{mg} / \mathrm{L})$ (Fig. 9).

The results of the mean concentrations of lead $(\mathrm{Pb})$ (Fig. 10) for the drinking water samples in the different studying sites were as follows (mg/L):- First, in AlKarkh region: Al-A'amel Neighborhood (0.100 \pm 0.03$)$, Hayfaa Street $(0.160 \pm 0.09)$, Al-Sarafiya Bridge $(0.130 \pm 0.08)$. Second, the results in the Al-Rusafa region: Kasraa Wa Ataash Neighborhood (0.170 \pm 0.05$)$, Al Fadhilia Neighborhood $(0.130 \pm 0.03)$, Bab AlMoatham Neighborhood $(0.150 \pm 0.06)$. Third, the results of Bottled Drinking Water: Pearl Company $(0.170 \pm 0.02)$,
Al-saad Company $(0.170 \pm 0.06)$, and Aquafina Company $(0.020 \pm 0.03)$.

These results confirm there is serious chemical pollution by lead. Additionally to the environmental impact, pollution of drinking water by lead in the major sources of drinking water in the city of Baghdad is a significant hazard to the health of public water consumers. The results revealed that the lead pollution in Al-A'amel Neighborhood (Tap Water) is ten times higher than the permitted international limit, while the pollution in Kasraa Wa Ataash Neighborhood (Tap Water), Pearl and Al-saad Companies (Bottled Drinking Water) increases 17 times. Pollution in the areas of Al-Sarafiya Bridge (Tigris River) and Al Fadhilia Neighborhood (Water Well) increases by 13 times and in Haifa Street (Water Well) increases 16 times, and in Bab Al-Moatham Neighborhood (Tigris River) increases 15 times, although Aquafina Company (Bottled Drinking Water) has concentrations of lead is about two times higher than the Iraqi and international

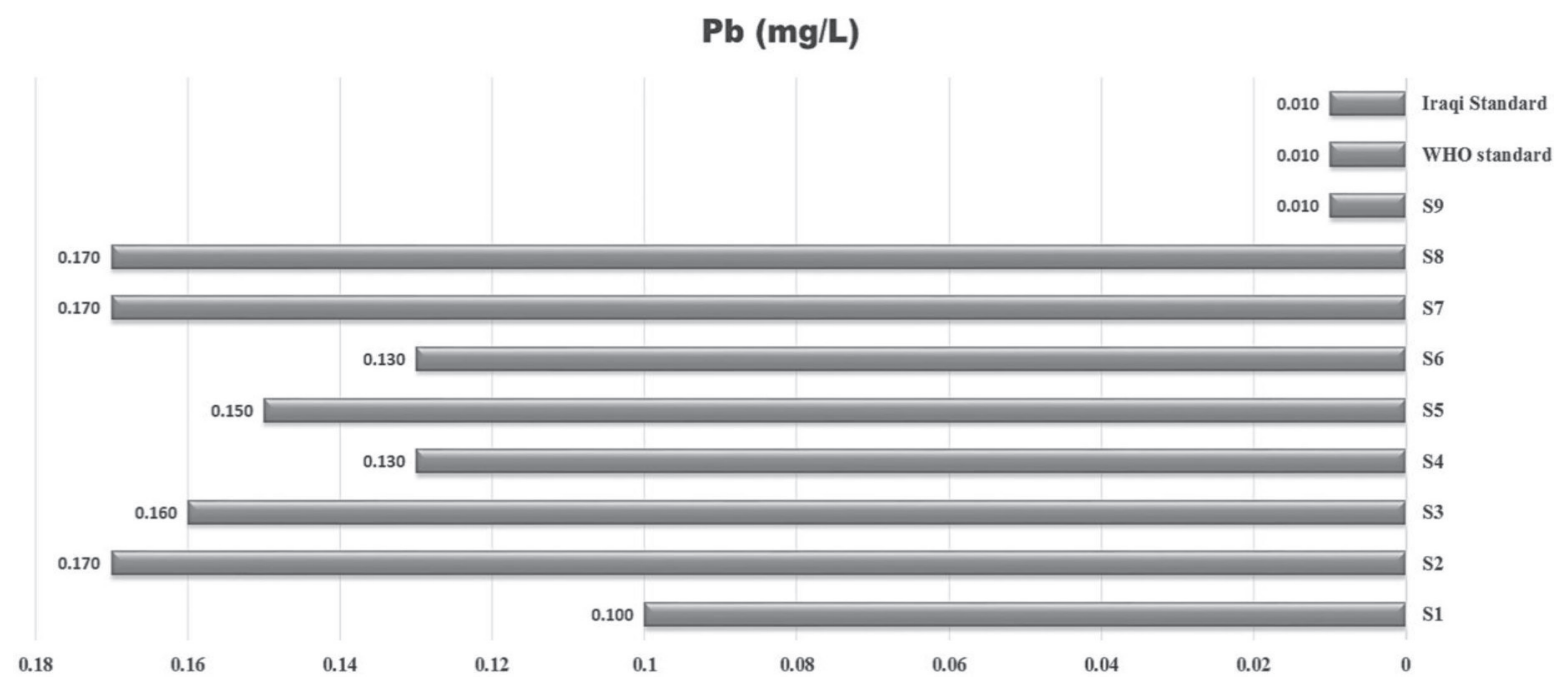

Fig. 10. Concentrations of $\mathrm{Pb}$ in different studied sites. 


\section{$\mathrm{Fe}(\mathrm{mg} / \mathrm{L})$}

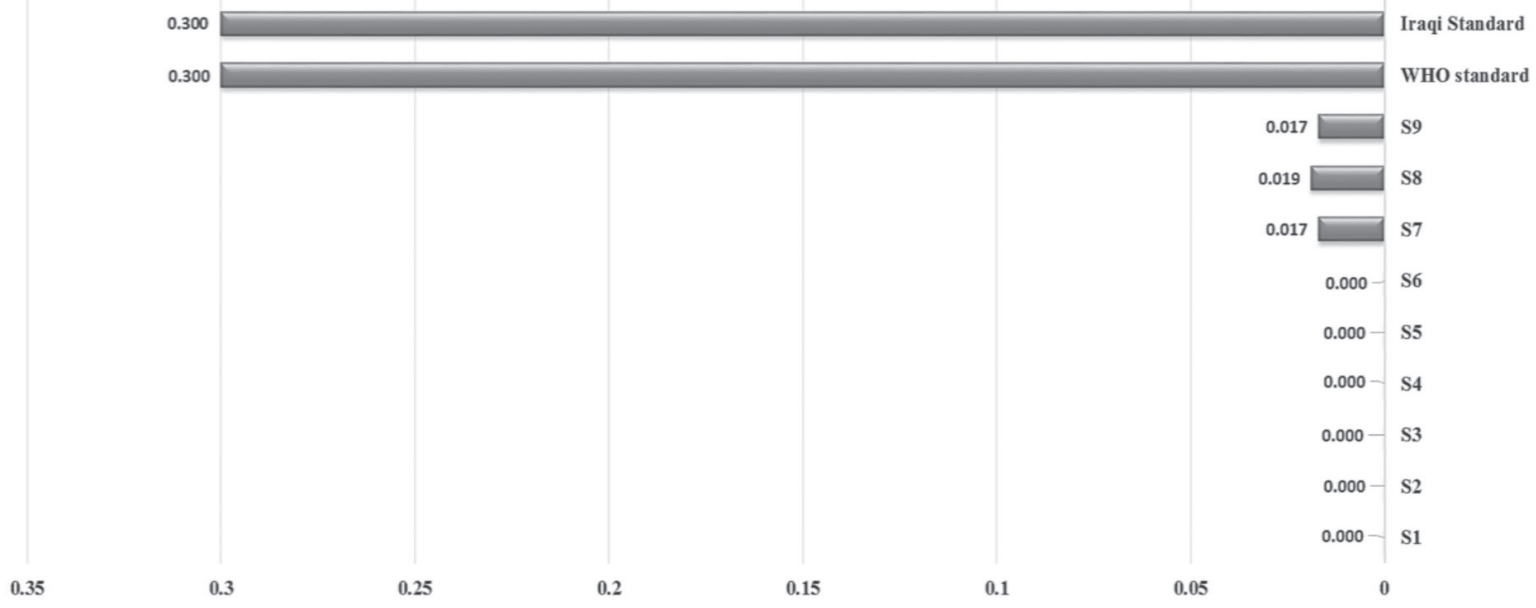

Fig. 11. Concentrations of $\mathrm{Fe}$ in different studied sites.

limits (Table 2). The highest rate of $\mathrm{Pb}$ drinking water pollution in Baghdad is the bottled drinking water and Tap water. Such results of the analysis may be defined as: bottled drinking water and tap water $>$ well water $>$ Tigris River.

The concentrations of iron (Fe) and nickel (Ni) in bottled drinking water samples showed a low mean concentration in all analyzed samples. The mean iron concentrations in bottled drinking-water samples are S7- $0.017 \pm 0.03 \mathrm{mg} / \mathrm{L}, \mathrm{S} 8-0.019 \pm 0.04 \mathrm{mg} / \mathrm{L}$ and $\mathrm{S} 9$ $0.017 \pm 0.01 \mathrm{mg} / \mathrm{L}$ mean nickel concentrations in bottled water samples are S7- $0.018 \pm 0.06, \mathrm{~S} 8-0.016 \pm 0.09$ and S9- $0.018 \pm 0.04$ (Figs 11 and 12); these data reflect there is no pollution of iron or its compounds in some drinking water sources in Baghdad city, and they are in a good agreement with the concentrations identified by the World Health Organization (WHO), together with some other international standards.

In Table 4, low $\mathrm{pH}$ values can be observed in bottled drinking water samples S7 (6.62), S8 (7.11) and S9 (6.80) with a low concentration of heavy elements in the same samples except for lead and copper. Nevertheless, the highest and lowest $\mathrm{pH}$ values calculated in this research were within the approved global and Iraqi drinking water limits ranging from 6.5-8.5.

The highest values of Total Dissolved Solids (TDS) for analyzed drinking water samples found in water wells in Hayfaa Street are $(2740 \mathrm{mg} / \mathrm{L})$ and in Al-Fadhilia Neighborhood are $(1720 \mathrm{mg} / \mathrm{L})$ while the lowest values found in bottled drinking water samples they are are $(5 \mathrm{mg} / \mathrm{L} ; 36 \mathrm{mg} / \mathrm{L} ; 22 \mathrm{mg} / \mathrm{L})$. Besides, TDS values in Al-A'amel Neighborhood are S1- $296 \mathrm{mg} / \mathrm{L}$ and in Kasraa Wa Ataash Neighborhood they are $341 \mathrm{mg} / \mathrm{L}$ (Tap Water) and the values of TDS have reached $386 \mathrm{mg} / \mathrm{L}$ and $312 \mathrm{mg} / \mathrm{L}$ in Bab Al-Moatham Neighborhood and Al-Sarafiya Bridge sequentially. Results of TDS analysis showed drinking water samples have high concentration of TDS in water wells in AlRusafa (about 2 times higher than the Iraqi and WHO limits) and in Al-Karkh it is about 3 times higher than

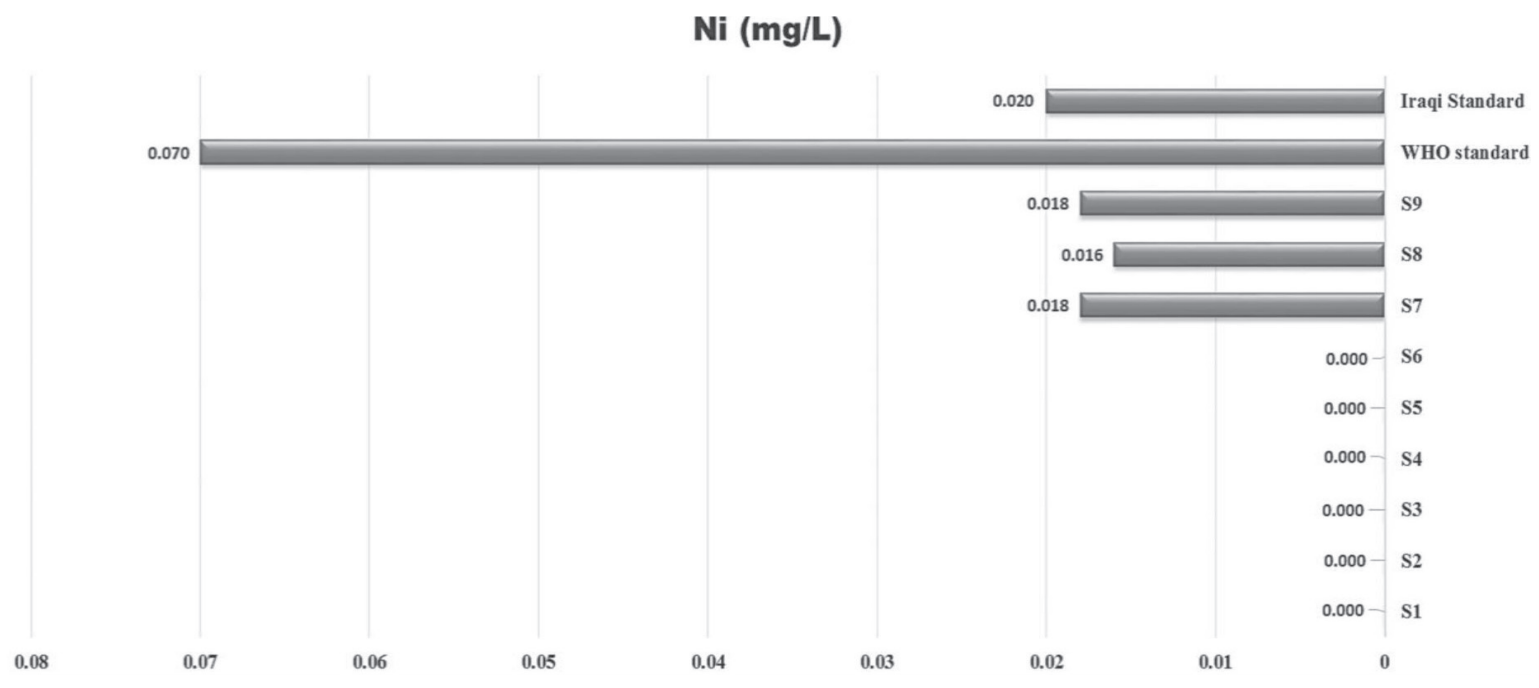

Fig. 12. Concentrations of $\mathrm{Ni}$ in different studied sites. 
Table 5. HPI for some heavy elements in water supply samples from selected locations in the City of Baghdad.

\begin{tabular}{|l|c|c|c|c|c|c|c|}
\hline Sample № & $\mathrm{Cd}$ & $\mathrm{Cr}$ & $\mathrm{Cu}$ & $\mathrm{Co}$ & $\mathrm{Fe}$ & $\mathrm{Pb}$ & $\mathrm{Ni}$ \\
\hline Site 1 (S1) & 42.18 & 1.58 & 0.08 & - & - & 9.85 & - \\
\hline Site 2 (S2) & 55.84 & 1.76 & 0.11 & - & - & 16.76 & - \\
\hline Site 3 (S3) & 58.52 & 2.20 & 0.08 & - & - & 15.56 & - \\
\hline Site 4 (S4) & 55.20 & 1.39 & 0.06 & - & - & 12.85 & - \\
\hline Site 5 (S5) & 58.56 & 1.53 & 0.22 & - & - & 14.70 & - \\
\hline Site 6 (S6) & 42.08 & 1.76 & 0.10 & - & - & 12.84 & - \\
\hline Site 7 (S7) & 39.65 & 1.33 & 0.23 & 9.25 & 0.05 & 16.75 & 0.22 \\
\hline Site 8 (S8) & 55.72 & 1.36 & 0.12 & 8.28 & 0.06 & 16.76 & 0.18 \\
\hline Site 9 (S9) & 2.69 & 0.25 & 0.03 & 9.24 & 0.05 & 1.86 & 0.22 \\
\hline Mean & 45.61 & 1.64 & 0.12 & 8.92 & 0.05 & 13.10 & 0.21 \\
\hline
\end{tabular}

the Iraqi and WHO limits because of the absence of the purification method to reduce total dissolved solids concentration, as well as the deficiency of water pressure in the water pipes leads to a mixture of drinking water with the other surrounding groundwater particularly when there is a leak or cracks in the network pipes. Effects of high TDS concentrations in drinking water can cause stiffness of the joints, hardening of the arteries, causing stone in the kidneys, gallstones and blockages of arteries where liquids flow through our bodies $[33,34]$. The other drinking water samples show low TDS concentrations compared with WHO, Iraqi standard and other organizations (Table 3).

In this work, we observed low turbidity values in samples of drinking water of Al-A'amel Neighborhood (2.49 N.T.U); Hayfaa Street had (2.70 N.T.U); Bottled Drinking Water: Pearl Company- had 0.08 N.T.U; Alsaad Company- included 1.40 N.T.U and Aquafina Company- had 0.15 N.T.U. These results are within the Iraqi and global limit (5 N.T.U). The high turbidity values found in the sites: Kasraa Wa Ataash Neighborhood (9.44 N.T.U), Al-Sarafiya bridge (30.23 N.T.U), Al Fadhilia Neighborhood (51.09 N.T.U) and Bab Al-Moatham Neighborhood (62.23 N.T.U). All the high turbidity samples (more than 5 N.T.U) exceeded by 2 times (S2), 6 times (S6), 10 times (S4) and 12 times (S5) respectively, the limits permitted for WHO and Iraqi guidelines. The index of turbidity values shows that the turbidity is less than 1 (5 NTU). Thus, we can classify our drinking water samples as follows: samples S7 and S9 are Goods; samples S1, S3 and S8 are fair and the samples S2, S4, S5, and S6 are Poor water [16]. High turbidity levels in drinking water are undesirable and threatening to health. Turbidity can provide food for many pathogens. Therefore, if the turbidity is not removed, this will lead to waterborne diseases, which cause momentous cases of gastroenteritis. Hence, increasing turbidity levels in drinking water may increase the risks for newborn and elderly populations.
The results of the Heavy Metal Pollution Index (HPI) estimate are illustrated in Table 5. According to HPI, the metals of certain drinking water sources in the city of Baghdad show varying rates of contamination. The findings obtained revealed that showing $\mathrm{Cd}$ and $\mathrm{Pb}$ seriously affected drinking water, with the exception of sites 9 displaying moderately to slightly affected. Chromium has a slight effect on drinking water while site 9 does not have any effect. The $\mathrm{Fe}, \mathrm{Ni}$, and $\mathrm{Cu}$ results were no effect. In Baghdad city the mean HPI of heavy metals was contained in drinking water sources as follows: $\mathrm{Cd}>\mathrm{Pb}>\mathrm{Co}>\mathrm{Cr}>\mathrm{Ni}>\mathrm{Cu}>\mathrm{Fe}$.

\section{Conclusions}

For this analysis, heavy metal concentrations were calculated by seven chosen elements for seven different sources of drinking water and three various kinds of bottled water. In addition, $\mathrm{pH}$, turbidity, and TDS were measured also in different drinking water sources in Baghdad city. Study time for all samples continued for the period from November 2018 to March 2019. The results show that the main drinking water sources (Tap Water, Water Wells, Tigris River, and Bottled Drinking Water) in Baghdad city which have been examined are almost polluted by heavy elements. The HPI values indicated that $\mathrm{Cd}, \mathrm{Pb}$, and $\mathrm{Co}$ were seriously affected by drinking water, while HPI ranged from no effect to slightly affect by other elements.

The main factors behind the increase of the pollution in drinking water sources in Baghdad city in particular and Iraq, in general, are automobile exhaust, irresponsible industrial activities, dumping hospital waste in the Tigris River, deficiency of advanced systems to extract heavy and toxic metals and ions from water, as well as the military operations and dangerous security conditions in the Baghdad city and continuous neglect of the government to find solutions for these problems. So, our recommendations to 
reduce the pollution levels in Baghdad drinking water sources: manufacturing facilities built along with the Tigris River should be improved to treat polluted water before being put into Tigris River, maintaining the drinking water pipes from the fractures or extending new pipelines, and developing a comprehensive plan to protect drinking water sources and ecological components in Baghdad city, considering it as a part of the national program and problem-solving of the ongoing power outage in Baghdad because of its impact on the stations of filtering and sterilization of drinking water reaching homes.

\section{Acknowledgements}

We are sincerely thankful for everyone who helped us in collecting, measuring and analyzing the samples in this work.

\section{Conflict of Interest}

The authors declare no conflict of interest.

\section{References}

1. MAALAH N., AL-Azzawi N. Pollutionary effect of the Medical city waste water on the Tigris river bacterial indicators on Baghdad city. Iraqi Journal of Science, $\mathbf{5 5}$ (1), 106, 2014.

2. ABBAS N., WASIMI S., Al-ANSARI N., SULTANA N. Water resources problems of Iraq: Climate change adaptation and mitigation. Journal of Environmental Hydrology, 26, paper 6, 2018.

3. HAYDER MOHAMMED ISSA, AZAD $\mathrm{H}$. ALSHATTERI. Assessment of Heavy Metals Contamination in Drinking Water of Garmian Region, Kurdistan, Iraq. Journal of Science and Technology, 2 (2), 40, 2018.

4. MOHAMMED FADHIL ABO-KSOUR. Occurrence of heavy metals levels in water and inhabitants of Iraqi marshes. IJISET-International Journal of Innovative Science. Engineering and Technology, 3 (5), 531, 2016.

5. WHO. Guidelines for Drinking-water Quality, Lead in Drinking-water; Publisher: WHO Press, Geneva, Switzerland, pp. 19, 2011.

6. BRAMA M., GNESSI L., BASCIANI S., CERULLI N., POLITI L., SPERA G., MARIANI S., CHERUBINI S., SCOTTO A., SCANDURRA R., MIGLIACCIO S. Cadmium induces mitogenic signaling in breast cancer cell by an ER $\alpha$-dependent mechanism. Molecular and Cellular Endocrinology, 264 (1-2), 102, 2007.

7. RAZIC S., DOGO S. Determination of chromium in Mentha piperita L. and soil by graphite furnace atomic absorption spectrometry after sequential extraction and microwave - assisted acid digestion to assess potential bioavailability. Chemosphere, 78, 451, 2010. DOI: https:// doi.org/10.1016/j.chemosphere.2009.10.028.

8. HASHEM E., SELEIM M., El-ZOHRY A. Environmental method for spectrophotometric determination of copper
(II). Journal Green Chemistry Letters and Reviews, 4, 241, 2011. DOI: https://doi.org/10.1080/17518253.2010.546370

9. WHO. Guidelines for Drinking-water Quality, Cobalt and Inorganic Cobalt Compounds; Publisher: WHO Press, Geneva, Switzerland, 93, 2006.

10. JADHAV H., SARKAR N., KATARIA M., TRIPATHI C. Subchronic exposure to a mixture of groundwatercontaminating metals though drinking water induces oxidative stress in male rats. Environ. Toxicol. Pharmacol, 23, 205, 2007.

11. DUDA-CHODAK A., BŁASZCZYK U. The Impact of Nickel on Human Health. J. Elementol, 13 (4), 685, 2008.

12. BARBOOTI M., BOLZONI G., MIRZA A., PELOSI M., BARILLI L., KADHUM R., PETERLONGO G. Evaluation of Quality of Drinking Water from Baghdad, Iraq. Science World Journal, 5 (2), 35, 2010.

13. MAY GEORGE KASSIR, LAMYAA MOHAMMED D., FATIN FUAD. Quality Assurance for Iraqi Bottled Water Specifications. Journal of Engineering, 21 (10), 114, 2015.

14. WHO. Guidelines for Drinking-water Quality, Total dissolved solids in Drinking-water. Available online: https://www.who.int/water_sanitation_health/dwq/ chemicals/tds.pdf 2003.

15. RADULESCU C., DULAMA I., STIHI C., IONITA I., CHILIAN A., NECULA C., ELENA DANIELA CHELARESCU. Determination of Heavy Metal Level in Water and Therapeutic Mud by Atomic Absorption Spectroscopy. Rom. Journ. Phys., 59 (9-10), 1057, 2014.

16. WHO. Water Quality and Health - Review of Turbidity: Information for regulators and water suppliers. Available online: https://apps.who.int/iris/bitstream/ handle/10665/254631/WHO-FWC-WSH-17.01-eng. pdf?sequence $=1 \&$ isAllowed $=y$ (2017).

17. BAYADER F. ABBAS, WESSAL M. KHAMIS A1JUBORI, AHMED M. ABDULLAH, HANAN K. SHAABAN, MUSTAFA TAHA MOHAMMED. Environmental Pollution with the Heavy Metal Compound. Research J. Pharm. and Tech, 11 (9), 4035, 2018.

18. MUHANAD H. ALRAKABI, ESRAA S. RAMADAN. Determination of Heavy elements in Drinking Water from Different Regions of Baghdad City (Iraq) Using EDXRF Spectrometer. Al- Mustansiriyah Journal of Science, 28 (1), 142, 2017. DOI: http: //doi.org/10.23851/mjs.v28i1.324

19. ALAA HAMED EMRAN AL-HUSSEINI. Risk assessment of heavy metals in tap drinking water in different age group; in Baghdad city, Iraq. Mesopotemia Environmental journal, 4 (2), 89, 2017.

20. KAMAL B. AL-PARUANY, ABDUL JABBAR A. ALI, KHALIL I. HUSSAINI, HUSAM SALEEM KHALAF, MAHASIN F. ALIAS. Assessment of Heavy Metals in Some Ground Water Wells at Baghdad City /Iraq. Journal of Global Pharma Technology, 10 (3), 62, 2018.

21. SAFAA NASSER HASSAN AL-HUSSAINI, ABDUL HAMEED M. JAWAD AL-OBAIDY, ATHMAR ABDUL MAJEED AL-MASHHADY. Environmental assessment of heavy metal pollution of Diyala River within Baghdad City. Applied Water Science, 8 (87), 2018. DOI: https://doi. org/10.1007/s13201-018-0707-9

22. Al-OBAIDY M., AWAD S., ZAHRAW Z. Impact of Medical City and Al-Rasheed power plant effluents on the water quality index value of Tigris River at Baghdad city. Engineering and Technology Journal, 34A (4), 715, 2016.

23. RICE E.W., BAIRD R.B., EATON A.D. Standard Methods for the Examination of Water and Wastewater. 23 $3^{\text {st }}$ edition; Publisher: American Public Health Association, American 
Water Works Association and the Water Environment Federation, Washington DC, USA, pp. 1545, 2017.

24. NOOR YASEEN SALIH, MUHAMMED N. A. The assessment of some physical and chemical parameters of drinking water quality in Al-Wahda and Al-Qadisiyah treatment plants at Baghdad, Iraq. Iraqi Journal of Science, Special Issue (Part B), 286, 2016.

25. SHITTU ABDULLAHI, CHIFU E. NDIKILAR, SULEIMAN A. B., HAFEEZ Y. HAFEEZ. Evaluation of Heavy Metal Concentration in Drinking Water Collected from Local Wells and Boreholes of Dutse Town, North West, Nigeria. Advances in Physics Theories and Applications, 51, 1, 2016.

26. CAERIO S., COSTA M. H., RAMOS T. B., FERNANDES F., SILVEIRA N., COIMBRA A., MEDERIOS G., PAINHO M. Assessing heavy metal contamination in Sado Estuary sediment: an index analysis approach. Ecolog. Indicators, 5, 151, 2005.

27. WHO (World Health Organization). Guidelines for drinking-water quality, fourth edition incorporating the first addendum; Publisher: WHO Press, Geneva, Switzerland, 631, 2017.

28. WHO. Water Quality Control and Surveillance in Iraq (Phase Two) (E3-11). Available online: https://www. unicef.org/evaldatabase/files/Iraq_2010-01_Evaluation_ report_E3-11_ME.pdf (May 2010).

29. Drinking Water Parameter Cooperation Project. Support to the revision of Annex I Council Directive 98/83/EC on the Quality of Water Intended for Human Consumption (Drinking Water Directive). Available online: https:// ec.europa.eu/environment/water/waterdrink/pdf/WHO_ parameter_report.pdf (11 September 2017).

30. EPA. The Drinking Water Standards and Health Advisories Tables, Office of Water U.S. Environmental Protection Agency Washington, DC, USA. Available online: https:// www.epa.gov/sites/production/files/2018-03/documents/ dwtable2018.pdf (March 2018).

31. Guidelines for Canadian Drinking Water Quality (Summary Table). Available online: https://www.canada. $\mathrm{ca} /$ content $/ \mathrm{dam} / \mathrm{hc}$-sc/migration/hc-sc/ewh-semt/alt formats/pdf/pubs/water-eau/sum_guide-res_recom/sum guide-res_recom-eng.pdf (June 2019).

32. SALMA BILAL, SAMI UR RAHMAN. Determination of Trace Elements in the Drinking Water of Hassan Abdal (Punjab), Pakistan. Journal of Scientific and Innovative Research, 2 (2), 372, 2013.

33. IRFAN SHEIKH. Cobalt Poisoning: A Comprehensive Review of the Literature. Journal of Medical Toxicology and Clinical Forensic Medicine, 2 (2), 5, 2016. DOI: https://doi.org/10.21767/2471-9641.100017

34. AMIT SHARMA, KUNDU S., HUJAZ TARIQ, KEWALRAMANI N., YADAV R. Impact of total dissolved solids in drinking water on nutrient utilisation and growth performance of Murrah buffalo calves. Livestock Science, 198, 17, 2017. DOI: https://doi. org/10.1016/j.livsci.2017.02.002 